\title{
Mineral fertilization and irrigation effects on fruiting and growth in stone pine (Pinus pinea L.) crop
}

\author{
V. Loewe ${ }^{1, a}$, A. Alvarez ${ }^{1}$, M. Balzarini ${ }^{2}$, C. Delard ${ }^{1}$ and R. Navarro-Cerrillo ${ }^{3}$ \\ ${ }^{1}$ Chilean Forest Institute (INFOR), Sucre 2397, Ñuñoa, Santiago, Chile \\ 2 CONICET Biometry Unit, College of Agriculture, Universidad Nacional de Córdoba, Av. Haya de la Torre s/n, Córdoba, \\ Argentina \\ ${ }_{3}^{3}$ Department of Forestry Engineering, ETSIAM, Universidad de Córdoba, Laboratorio de Repoblaciones Forestales, Campus \\ de Rabanales. Edif. Leonardo da Vinci, Crta. N-IV-a Km. 396, Córdoba, Spain
}

\section{Summary}

Introduction - Stone pine (Pinus pinea L.) is a species of economic interest for its pine nuts. Despite this market, cones are harvested mostly from natural forests. Advances in semi-intensive or intensive management for cultivating it as a fruit tree have been scarce. Fruit development is characterized by a 3 -year cycle since pollination to harvesting, making nutritional and hydric management highly challenging. Materials and methods - We studied the main and interaction effects of fertilization and irrigation on growth and fruiting by a factorial design laid out in an adult stone pine plantation located in central Chile. Results and discussion - Mineral fertilization had an effect one year later on height growth $(+23.5 \%$ increase) and one-year-old conelet production $(+82.3 \%$ increase). After two consecutive years of mineral fertilization, significant positive impacts on diameter growth, height growth and one-year-old conelet production were observed. Irrigation enhanced fruiting but did not impact growth significantly. The highest conelet number was observed in the fertilized and irrigated experimental plots. Conclusion - Both cultural practices, applied either individually or combined, are efficient techniques to enhance fruit production of the stone pine.

\section{Keywords}

Chili, stone pine, Pinus pinea, mineral nutrition management, pine conelet, pine nut, water supply management

\section{Résumé}

Effets de la fertilisation minérale et de l'irrigation sur la croissance et la production fruitière du pin pignon (Pinus pinea L.).

Introduction - Le pin parasol (Pinus pinea L.) est une espèce d'intérêt économique pour ses pignons. Malgré ce débouché, les cônes sont récoltés essentiellement à partir de forêts naturelles. Rares sont les progrès en gestion semi-intensive ou intensive pour le cultiver comme un arbre fruitier. Le développement des fruits se caractérise par un cycle de 3 ans depuis la pollinisation jusqu'à la récolte, rendant la gestion minérale et hydrique particulièrement diffi-

\section{Significance of this study}

What is already known on this subject?

- This is the first study on fertilization and irrigation in an adult intensive $P$. pinea plantation, providing a first management proposal for the species.

What are the new findings?

- Fertilization enhanced fruit production (>82.3\%) and vegetative growth while irrigation enhanced only fruiting. Best fruit production was recorded in fertilized and irrigated plots $(>60 \%)$.

What is the expected impact on horticulture?

- Pine nuts can be produced in orchards applying horticulture techniques as in other fruit crops, improving production quality and quantity, overcoming the traditional view as a non-timber forest product (NTFP).

cile. Matériel et méthodes - Nous avons étudié les effets principaux et en interaction de la fertilisation minérale et de l'irrigation sur la croissance et la fructification selon un plan d'essai factoriel aménagé dans une plantation adulte de pins parasols située au centre du Chili. Résultats et discussion - La fertilisation minérale a eu un effet après un an d'application sur la croissance en hauteur $(+23,5 \%)$ et sur la production de cônes d'un an $(+82,3 \%)$. Après deux années consécutives de fertilisation minérale, des effets positifs notables ont été observés sur la croissance du diamètre de l'arbre, la croissance en hauteur et la production de cônes d'un an. L'irrigation a amélioré la fructification mais n'a pas eu d'impact significatif sur la croissance des arbres. Le nombre de cônes le plus élevé a été observé dans les parcelles expérimentales fertilisées et irriguées. Conclusion - Les deux pratiques culturales appliquées individuellement ou combinées sont des techniques efficaces pour améliorer la production fruitière du pin à pignon.

\section{Mots-clés}

Chili, pin parasol, Pinus pinea, pignon de pin, cône de pin, gestion de la nutrition minérale, gestion de l'eau 


\section{Introduction}

Stone pine (Pinus pinea L.) is an important species for its pine nuts, which have a high nutritional value (Segura and Lizarraga, 2006). It is one of the most expensive nuts worldwide and the oldest dry fruit tree, as demonstrated by archaeological remains that evidence its cultivation in the pre-Christian era (Rottoli and Castiglioni, 2011). Despite the traditional use of this nut, fruits are harvested mostly from natural forests located in the Mediterranean Basin. Advances in semi- or intensive cultivation techniques as a fruit tree have been scarce (Mutke et al., 2012). Stone pine is characterized by a long cycle of cone development (42 months), with one-, two- and three-year-old cones occurring simultaneously on the tree, a characteristic that makes nutritional and hydric management more complex than in traditional fruit trees (Loewe and Delard, 2012).

The species has been widely planted in European Mediterranean areas and managed as a forest tree. Given its resistance to drought and low soil fertility, it has been planted across a wide range of environments, not always adequate for the species, which often expose the trees to multiple stresses. Irrigation and fertilization during the productive stage can help to surpass the seasonal water shortage and compensate nutritional deficits, but only a few studies have addressed this topic.

The appropriate management of fertilization and irrigation is essential for cropping fruiting species (Calama et al., 2007; Tagliavini, 2014) as well as for pine species, such as Pinus pinaster (Zas and Fernández-López, 2005), P. edulis and P. monophylla, to stimulate cone production (McLain, 2008), but information about P. pinea is scarce (Marschner, 2012; Sansavini and Ranalli, 2012). Some authors have studied fertilization effect on stone pine plant production in nursery (Borrero, 2004; Ruano, 2008) and immediately after plantation (Cañellas et al., 1999), showing that the use of slow release NPK fertilizers increases height growth during the first years, although it reduces shoot frost resistance (Villar-Salvador et al., 2005) as in other Pinus species (Li et al., 2016). In the species' young or adult plantations or forests, the existing information is only for forest management while effects on cone production have not been previously referred. Cone production and quality expressed as size was monitored in a 45-year-old forest, and found a positive response to fertilization in the quantity and quality of cones, especially under a high dose of dolomite (calcium magnesium carbonate) (Calama et al., 2007). Nutrient effect was studied in Turkey, showing a positive correlation between nitrogen, phosphorus, calcium and manganese depletion in needles and cone loss (Kilci, 2013), and recommended not applying phosphorus and calcium in drought-stricken areas, since they might contribute to cone loss. In Chile, a significant effect has been reported of fertilization on female flower production in a 16-year-old plantation, with 41 and 54\% increase in strobili one and two years after fertilization, respectively (Loewe et al., 2012).

The impact of micronutrients on P. pinea is unknown. Iron deficiency was studied in Israel, and found to significantly decrease root growth and to induce a reduction in chlorophyll concentration on needles in soils with high concentration of calcium carbonate, a high soil $\mathrm{pH}$ being the cause for reduced iron absorption (Malchi and Shenker, 2011).

Irrigation is extremely important for cultivated Mediterranean fruit trees (Lodolini et al., 2014) even if the species is drought resistant (Loewe and Delard, 2012; Castaño et al., 2004). Stone pine has been reported as hydraulic superior to other Mediterranean species in terms of water use efficiency (Oliveras et al., 2003). However, water deficit was found to limit cone production along a climatic gradient in Chile, especially related to spring hydric index (HI; Hydric index = Rainfall - Potential Evapotranspiration) (Loewe et al., 2016). Accordingly, minimum average temperature and hydric index affected female flowering, annual rainfall affected male flowering, and thermal oscillation influenced differentiation of reproductive shoots. Winter rainfall is also very important in flowering and fruiting in Mediterranean areas (Calama et al., 2007).

The objective of this study was to quantify the effect of fertilization and irrigation in growth and fruiting in a stone pine adult plantation, based on the hypothesis that fertilization and irrigation, if applied in combination, would enhance fruiting more than if applied separately, since fruiting would strongly correlate to plant growth and nutrient storage.

\section{Materials and methods}

\section{Experimental trial}

The experiment was conducted in a 30-years-old stone pine plantation located in Cáhuil ( $\left.34^{\circ} 30^{\prime} \mathrm{S}, 71^{\circ} 59^{\prime} \mathrm{W}\right)$, Chile, at $125 \mathrm{~m}$ a.s.l., on smooth hills with silty clay loam soil of granitic origin (UF2 according to FAO soil description). The plantation was established with one-year-old Pinus pinea seedlings, with minimum local soil preparation, in winter 1983, with the aim of controlling erosion. A first thinning was applied 20 years after establishment, extracting $50 \%$ of trees, and the first pruning and a second thinning extracting $65 \%$ of trees were conducted 30 years after establishment, leaving an average density of 285 trees ha-1 $^{-1}$, prior to the fertilization and irrigation experiment beginning.

The climate in the area is typically Mediterranean, characterized by long dry summers and short intense winter rainfall, with maritime influence given its closeness to the Pacific Ocean. Average annual climate data (2004 to 2014) indicate annual rainfall is $416.3 \mathrm{~mm}$, with an annual evapotranspiration of $1,201.2 \mathrm{~mm}, 8.6$ dry months [dry month = (monthly rainfall $/$ monthly evapotranspiration) $<0.5$ ] per year, and annual average temperature of $13.2^{\circ} \mathrm{C}$ (www.dga.cl; www.inia.cl). Average initial soil properties, including nutrient composition, were determined by a composite of 6 subsamples, following a zigzag transect at three depths (Table 1$)$. The soil is slightly acid $(\mathrm{pH}=5.85)$, medium organic matter content (3.6\%), and no salt (E.C.

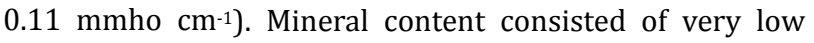
phosphorus, boron and sulphur content; low nitrogen and potassium content; medium copper, zinc and iron, and high manganese content.

The experimental trial was installed in 2013, testing the following treatments: control, irrigation in spring and summer, fertilization applied in spring and fall, and the combination of both, using a $2 \times 2$ factorial treatment arrangement in a split-plot block design with three replicates. The primary treatment was fertilization and the secondary treatment irrigation; finally, the combined treatments were as follows:

T0: control;

T1: only fertilized;

T2: only irrigated; and

T3: fertilized and irrigated.

Control received neither fertilization nor irrigation. Each block had 25 trees per treatment, totaling 300 trees for the whole trial. In 2015 we assessed the effect of two years of fertilization for the fertilized plots and one year of irrigation. 
TABLE 1. Response of vegetative growth and fruiting to the application of fertilization, irrigation and their combination in an adult stone pine plantation.

\begin{tabular}{|c|c|c|c|c|c|c|c|}
\hline \multirow[t]{2}{*}{ Treatment } & \multicolumn{2}{|c|}{$\begin{array}{l}\text { Height } \\
\text { (m) }\end{array}$} & \multicolumn{2}{|r|}{$\begin{array}{l}\mathrm{DBH} \\
(\mathrm{cm})\end{array}$} & \multicolumn{2}{|c|}{$\begin{array}{l}\text { Crown diameter } \\
(\mathrm{m})\end{array}$} & \multirow{2}{*}{$\begin{array}{c}\begin{array}{c}\text { 1-year-old } \\
\text { conelet number } \\
\text { tree-1 }\end{array} \\
2015 \\
\end{array}$} \\
\hline & 2013 & Growth 2013/15 & 2013 & Growth 2013/15 & 2013 & Growth 2013/15 & \\
\hline Control & 5.5 & $0.44 b c \pm 0.03$ & 15.9 & $2.75 \subset \pm 0.18$ & 3.4 & $0.68 \pm 0.14$ & $9.9 d \pm 0.10$ \\
\hline Irrigation & 5.8 & $0.40 c \pm 0.03$ & 16.1 & $2.78 b c \pm 0.18$ & 3.7 & $0.79 \pm 0.14$ & $11.4 c \pm 0.10$ \\
\hline Fertilization & 6.1 & $0.53 a \pm 0.03$ & 16.8 & $3.23 a b \pm 0.18$ & 3.6 & $0.74 \pm 0.14$ & $13.5 b \pm 0.10$ \\
\hline Irrigation \& Fertilization & 5.5 & $0.48 a b \pm 0.03$ & 15.8 & 3.28 a \pm 0.18 & 3.3 & $0.80 \pm 0.14$ & $15.8 \mathrm{a} \pm 0.10$ \\
\hline Average & 5.7 & 0.47 & 16.2 & 3.01 & 3.5 & 0.76 & 12.71 \\
\hline
\end{tabular}

Different letters indicate significant differences between treatments $(P<0.05)$. Deviation expressed as standard error of mean (SE).

Rates and application dates of fertilized plots were determined according to soil deficiencies identified through soil analyses. In spring 2013 (September), trees of fertilized treatments were treated with nitrogen ( 360 g plant $\left.^{-1}\right)$, phosphorus (75 g plant $\left.^{-1}\right)$, potassium $\left(75\right.$ g plant $\left.^{-1}\right)$, magnesium (30 g plant $\left.^{-1}\right)$, sulphur $\left(77\right.$ g plant $\left.^{-1}\right)$, boron $\left(7\right.$ g plant $\left.^{-1}\right)$, iron (1 g plant $^{-1}$ ) and zinc (5 g plant $^{-1}$ ). During the following autumn (March), and in an attempt to obtain nutrient load ( $\mathrm{Li}$ et al., 2016), these plots received a second fertilization application with phosphorus (161 g plant $^{-1}$ ), calcium ( 49 g plant $^{-1}$ ) and nitrogen (92 g plant $^{-1}$ ). In the second year, both fertilizations (spring and autumn) were repeated. Fertilizers were applied locally in two lateral strips located at the edge of the crown projection at $5 \mathrm{~cm}$ depth.

Irrigation treatments were established in spring 2014 and involved a drip irrigation system. The irrigation rate was defined according to the hydric deficit (HI) as an indicator of water deficit (HI = Rainfall - Potential Evapotranspiration), and was applied daily from spring 2014 to the end of summer 2015 (6 months), totaling $753 \mathrm{~L}^{\text {tree- }}{ }^{-1}$.

\section{Growth and fruiting measurements}

Growth and fruit production variables were recorded at the beginning of the trial, before fertilizing (spring 2013), and during the springs of 2014 and 2015. Diameter at breast height (DBH, cm), total height (m) and crown diameter (m) were measured in all trees. Diameters were measured to the nearest $0.1 \mathrm{~cm}$ with a graduated caliper in two perpendicular directions. A paint mark was made at $1.30 \mathrm{~m}$ above the ground line to ensure that diameter measurements were taken at the same point. Tree height was measured to the nearest $0.1 \mathrm{~m}$ with a hypsometer. Crown diameter was defined as the distance between the crown projections of living branches. In spring (November) all conelets from each tree were counted using a ladder to ensure that the entire crown was assessed. One-year old conelets were identified by their position in the terminal apexes and by their length (below $3 \mathrm{~cm})$.

\section{Statistical analysis}

From 2015 data, effects of two years of fertilization, one year of irrigation and their interactions were assessed using analysis of variance (ANOVA) for a split-plot design with complete blocks as repetitions. Linear mixed models were used for biannual height, DBH and crown growth, and a generalized linear mixed model for the number of one-year-old conelets (Poisson distribution, log link). Initial growth measurements (2013) were used as covariates. When ANOVA results showed significant effects, a post-hoc LSD's test was performed for multiple comparisons among adjusted means $(\alpha=0.05)$. Residual analyses were performed and observations with standardized residuals outside $(-3-3)$ interval were dropped. Correlations between growth measurements and one-year-old conelet number were explored using Regression Tree algorithm (Breiman, 2001). As confirmatory analysis we performed a non-parametric ANOVA to evaluate statistical significance of differences between yield mean groups suggested by the thresholds of the first RT nodes. Statistical analyses were performed using the software Infostat (Di Rienzo et al., 2013) and its interface with R (www.r-project.org).

\section{Results and discussion}

\section{Effects of treatments on vegetative growth}

The interaction of irrigation and fertilization was not significant $(P>0.05)$ for any of the growth and production variables (Table 1). However, irrigation and fertilization promoted diameter at breast height (DBH) growth differently, with fertilization having the strongest effect. Fertilization showed a significant effect on biannual DBH growth $(P=0.0045)$ and height $(P<0.05)$, whereas irrigation effect on DBH and height growth was not significant $(P>0.05)$. The significant effect of fertilization on height growth $(P<0.0001)$ was observed already in the first year after application, being height $23.5 \%$ higher in fertilized than in non-fertilized plots. Two years after the application, this increase was less pronounced (13.6\%; Figure 1). The effects of fertilization and irrigation, individually or combined, on biannual crown diameter growth $(P>0.05)$ were also non-significant (Table 1; Figure 2).

Cultural treatments in stone pine - fertilization and irrigation - have been scarcely studied and applied in production plantations, even though they are recognized as useful tools for enhancing growth and fruiting in most of the cultivated fruit trees (Tagliavini, 2014; Xyloyannis, 2014). We observed an important impact of fertilization on vegetative growth.

Regarding tree growth, one year after treatment, fertilized trees exhibited statistically higher height growth than non-fertilized trees (17 vs. $21 \mathrm{~cm}^{\text {year-1)}}{ }^{-1}$, representing a $23.5 \%$ increase. These results are consistent with Ravazi et al. (2006), who reported a significant effect of macronutrient fertilization on height and needle growth in poor soils in Iran, indicating that nitrogen is the most limiting element, and with Rapp et al. (1979) who reported that in a French stone pine forest aged 35 years, the nitrogen uptake from the soil was $46 \mathrm{~kg} \mathrm{ha}^{-1}$ year-1. $^{-1}$ 


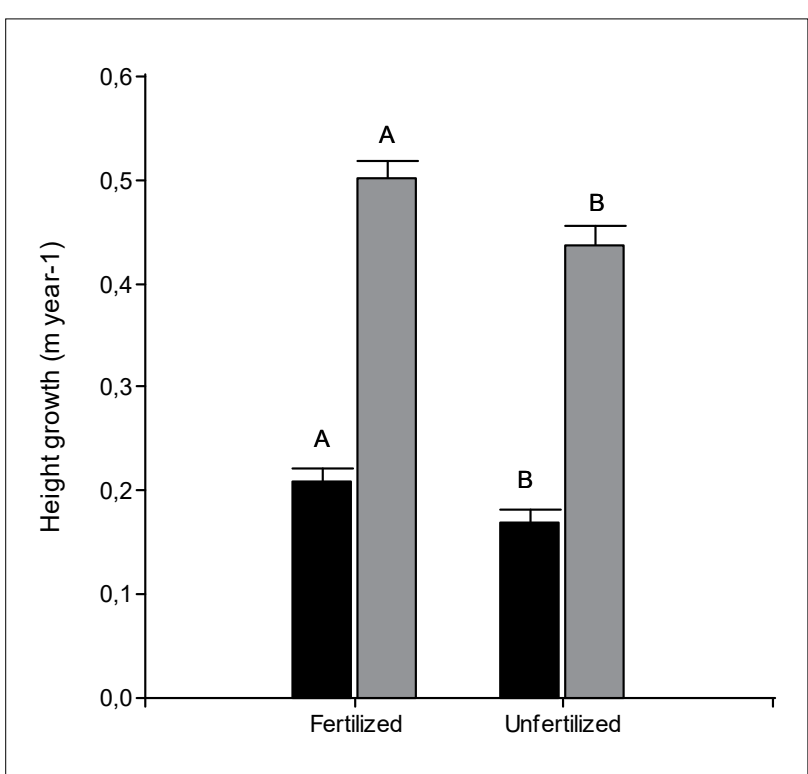

FIGURE 1. Height growth in fertilized and non-fertilized plots one (black) and two (grey) years after fertilizer application in an adult stone pine plantation. Different letters indicate statistically significant differences $(P<0.05)$.

Nutrition impact on $P$. tropicalis Morelet was studied by Ferrer et al. (2004), indicating that NPK deficiencies affect diameter growth and leaf dry weight, with $\mathrm{P}$ being the main limiting nutrient. In addition, Schlatter and Gerding (1984a, 1984 b) concluded that boron deficiencies in P. radiata D. Don plantations in Chile limited growth and could cause malformations.

In the studied plantation, tree size observed at age 30 years was similar to values reported by Calderón et al. (2008) for irrigated 17-year-old stone pine trees in a dense plantation in Mendoza province, Argentina (DBH $=17 \mathrm{~cm}$, height $=$ $6.6 \mathrm{~m}$ ), where climate and soil conditions are similar, indicating the relevance of water availability for stone pine growth.

In Chile, a positive effect of irrigation on DBH and height growth was previously observed (Loewe et al., 2015). In fact, irrigation can increase height growth up to $75 \%$ in the north of Chile, where temperatures and water deficits are high. Even in moist environments (with annual rainfall $<1,400$ $\mathrm{mm}$ ), irrigation increased height growth by $21 \%$ and $\mathrm{DBH}$ growth by $25 \%$.

Our results on $\mathrm{DBH}$, height and crown diameter were not favored by the irrigation treatment; although, first-year summer irrigation appeared to be a positive and not excessively expensive option (Pardos et al., 2015) to maintain soil water content above a threshold of survival. In this context, the effect of irrigation on growth in an adult plantation differs from Butler et al. (1997), who conclude that drip irrigation on a weekly basis has a positive effect on growth (up to $85 \%$ increase in DBH and up to $48 \%$ in crown diameter).

Regarding the combined effect of fertilization and irrigation, Pestaña (2000) evaluated the impact of fertirrigation in a 75-year-old plantation established in a clay-sand soil, using a sprinkler irrigation system with increasing doses from 2,460 to $5,480 \mathrm{~m}^{3}$ ha-1 $^{-1}$ year-1, and obtained a positive diameter growth response, increasing from 1 to $7 \mathrm{~mm}_{\text {year-1. }}{ }^{-}$. Our results are in agreement but of lower magnitude, i.e., an increase of 9\% in height growth, 19\% in DBH growth and $18 \%$ in crown diameter growth.

\section{Effects of treatments on fruiting performance}

We observed significant effects of fertilization $(P<0.0001)$ and irrigation $(P=0.0276)$ on one-year-old conelets production, with the highest conelet number observed in the combined treatment (Figure 2; Table 1). Fertilization effect was greater than irrigation effect. The positive effect of fertilization was observed one year after application, when a higher number of one-year-old conelets was recorded in fertilized plots than in the control (Figure 3). Two years after applications, fertilized plots had a one-year-old conelet production on average $36 \%$ higher than the control plot $(P<0.0001)$. The effect of both fertilization and irrigation had a more pronounced effect on one-year-old conelet production (59.6\% increase) in comparison with untreated plots.

We observed an important impact of fertilization on fruit production. In fact, individual production ranged between

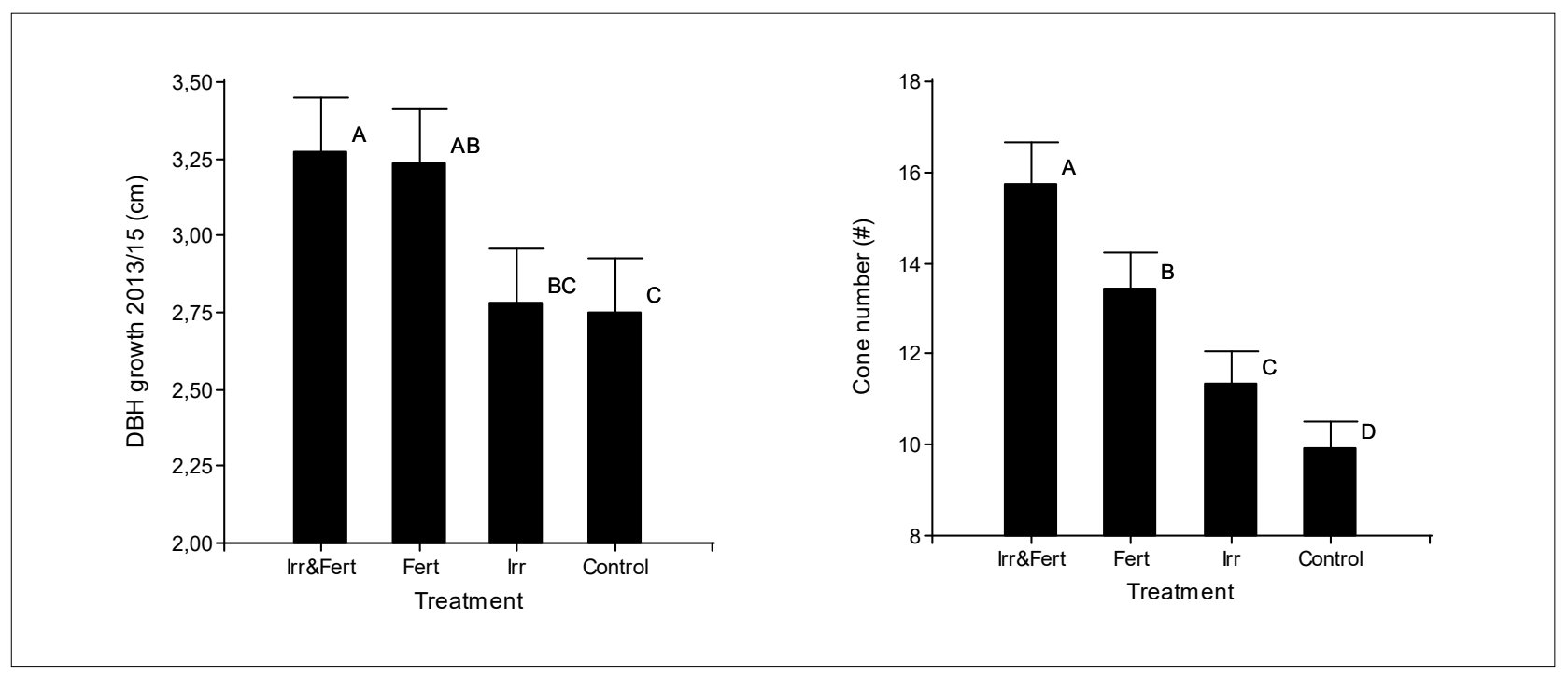

FIGURE 2. Fertilization and irrigation effects on diameter at breast height (DBH) growth and fruiting in a 32-year-old stone pine plantation in Chile. Different letters indicate statistically significant differences $(P<0.05)$. Irr: Irrigated plots; Fert: fertilized plots; Irr\&Fert: Irrigated and fertilized plots. 


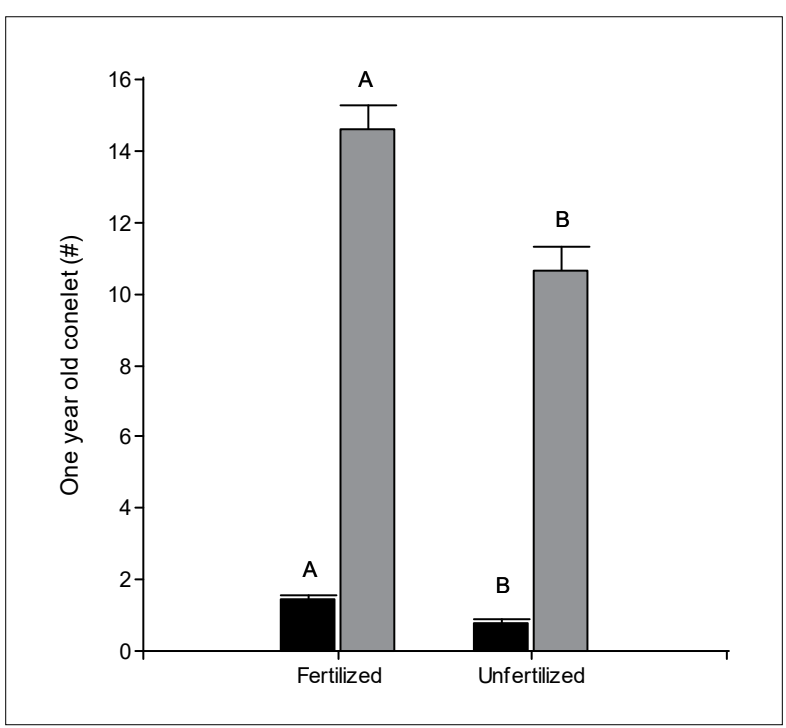

FIGURE 3. One-year-old conelet production in fertilized and non-fertilized plots one (black) and two (grey) years after fertilization application in an adult stone pine plantation. Different letters indicate statistically significant differences $(P<0.05)$.

9.9 and 15.8 one-year-old conelet tree ${ }^{-1}$, depending on the treatment; these values, however, are below the national

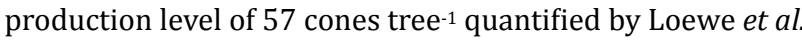
(2016), which could be due to the high density at which the plantation was maintained before management and trial establishment.

Fertilization also increased fruiting one year after application ( 0.79 vs. 1.44 conelet tree-1) $^{-1} 1.44$ representing an increase of $82.3 \%$ compared to the control. The effect after two consecutive years of fertilization was also significant (9.9 vs. 13.5 conelet tree ${ }^{-1}$ ), representing a $36.4 \%$ higher production.

These results are consistent with and higher than findings reported by Loewe et al. (2012) and are also in agreement, though to a lower degree, with Calama et al. (2007), who analyzed the effect of repeated fertilization on cone production and quality during 3 years in a 45 -year-old forest located on poorly drained, slightly acidic soils. The authors tested different rates of lime superphosphate, dolomite (calcium magnesium carbonate) and potassium chloride, and found a positive response of cone number to fertilization (up to 3.2 times higher cone production than in the control in the best-performing treatment, amounting to $1,500 \mathrm{~kg} \mathrm{ha}^{-1}$ ) and quality of cones produced, expressed as size, especially when more dolomite was incorporated. The authors observed that the best cone production was achieved 4 and 5 years after fertilization with high rates of phosphorus, potassium chloride and dolomite, with the latter being the most influential mineral. However, they consider this effect to derive from the higher vegetative growth and carbohydrate availability rather than to a direct nutritional effect.

According to Codesido and Merlo (2007), nitrogen supply influences flower induction in P. radiata; this effect is more pronounced if nitrogen is applied in early spring, when male and female flowering occur, favoring pollen production. In addition, nitrogen enhances tree vigor, which is correlated to strobili number (Mutke, 2005). Thus, we concentrated nitrogen supply in the spring rate, and our results confirm the observations of these authors.

In Turkey, Loewe and Delard (2015) found that fertiliza-

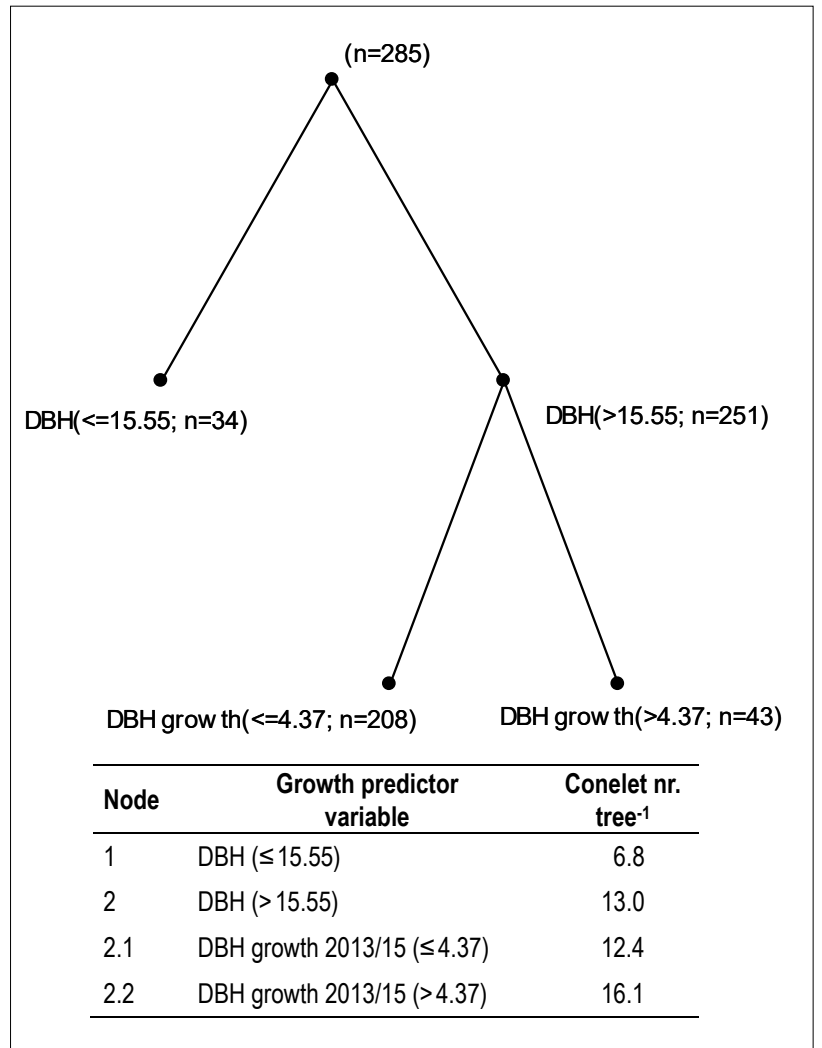

FigurE 4. Diameter at breast height (DBH) values that best explain one-year-old conelet tree- ${ }^{-1}$ in an adult stone pine plantation located in Chile. Nodes represent DBH values or growth identified as relevant to explain productivity. Total conelet production data were first split into two subsets based on the DBH threshold. Each subset, or node, was then analyzed independently using the same procedure. Variables forming the top nodes are the most important to explain fruiting. Conelet number at each node is reported in the embedded table.

tion increased cone weight by $33 \%$ and also number of pine nuts per cone.

Irrigation also increased the cone number tree ${ }^{-1}$, cone weight and in-shell pine nut number cone-1, with a significant effect on stone pine cone production (35\% compared with non-watered trees) (Loewe et al., 2016).

Our results on irrigation effect agree with those reported by Butler et al. (1997), who conclude that drip irrigation on a weekly basis has a positive effect on fruit production (up to 15 times higher cone production), but are of lower magnitude. This difference could be due to the effect of the ocean proximity, which tends to reduce vapor pressure deficits and water stress (Larcher, 2003), or to the high soil lime content that could interfere with the effects of irrigation.

While we only assessed the number of conelets, there is evidence that irrigation not only increases number of cones but also cone weight, which can be up to $15 \%$ higher in irrigated plantations (Bono and Aleta, 2013). This information shows the need for further research in order to learn how to optimize fertilization and irrigation in pine nut production in plantations. Moreover, in light of climate change, we consider that irrigation can mitigate the impacts of elevated temperatures on tree mortality and vitality. These management options, especially irrigation, will depend upon local water reservoirs and future climate change projections. 
Finally, we studied the relationships between growth and one-year-old conelet production using a regression tree algorithm (Figure 4); the results showed with statistical significance that fruiting performance was correlated to vegetative growth in adult trees. In fact, one-year-old conelet number was influenced by DBH, with thicker trees $(>15.6 \mathrm{~cm})$ bearing a higher number of one-year-old conelets than thinner trees (13 vs. 7 one-year-old conelet tree-1) $(P<0.0001)$. Thicker trees that grew faster also produced a higher number of one-year-old conelets; in fact, if biannual growth was above $4.4 \mathrm{~cm}$, production was $33 \%$ higher $(16 \mathrm{vs}$. 12 one-year-old conelet tree ${ }^{-1}$ ).

Here, we evaluated irrigation and fertilization for a short period (one and two years); for this purpose, field trials should be implemented, maintained and evaluated over a long period under different environmental conditions, to assess their impact also on the masting habit characteristic of the species (Calama et al., 2011) and to optimize application rates and their combination with other cultural practices.

Future studies should also address the use of fertirrigation on pine nut quality, considering that Borrero (2004) reported an increase in pine nuts concentrations of fat, copper, magnesium and sodium in fertilized plots.

Considering field performance, fertilization costs are more affordable than those of combined fertilization and irrigation. In fact, irrigation systems are expensive and would make stone pine less competitive than other crops (McLain, 2008; Castaño et al., 2004). However, there are innovative irrigation systems that should be evaluated because they do not require electricity supply or urban water access (Omodei, 2014).

\section{Conclusion}

Based on growth and production measurements, our results indicate that stone pine fertilization applied during two consecutive years is a useful tool to enhance DBH and height, and one year-old conelet production. This effect was independent of water availability, being an important practice in zones with soil limitations; these results confirm the advantage of establishing fertilized plantations for increasing growth and fruit production.

Irrigation had an important effect on fruiting, but effects on vegetative growth were non-significant. Maximum one-year-old conelet number tree-1 and vegetative growth (diameter at breast height and crown diameter) values were observed in the combined fertilization and irrigation treatment.

Understanding the effects of fertilization and irrigation on the species will require implementing and monitoring field trials over a longer period under different environmental conditions.

\section{Acknowledgments}

This work was supported by FONDEF, Chilean Ministry of Education (grant code D11I1134). The authors thank Araneda family that actively collaborated with the trial establishment and maintenance, and acknowledge the support from University of Córdoba-Campus de Excelencia CEIA3, Spain.

\section{References}

Bono, D., and Aleta, N. (2013). Cone yield evaluation of a grafted Pinus pinea L. trial. Opt. Méditerr. 105, 35-42.
Borrero, G. (2004). El pino piñonero (Pinus pinea L.) en Andalucía: ecología, distribución y selvicultura (Sevilla, Spain: Consejería de Medio Ambiente, Junta de Andalucía), 261 pp.

Breiman, L. (2001). Random Forests. Mach. Learn. 45(1), 5-32. https://doi.org/10.1023/A:1010933404324.

Butler, I., Abellanas, B., Monteagudo, F., Bastida, F., and López, J. (1997). First results of a plot trial in agronomic grafting techniques in stone pine at the experimental farm 'El Cebollar'. Proc. $2^{\text {nd }}$ Spanish Forest Congress 2, 99-104.

Cañellas, I., Finat, L., Bachiller, A., and Montero, G. (1999). Comportamiento de planta de $P$. pinea en vivero y campo: ensayo de técnicas de cultivo de planta, fertilización y aplicación de herbicidas. Inv. Agr: Sist. Rec. For. 8(2), 335-360.

Calama, R., Madrigal, G., Candela, J.A., and Montero, G. (2007). Effects of fertilization on the production of an edible forest fruit: stone pine (Pinus pinea L.) nuts in the south-west of Andalusia. Inv. Agr: Sist. Rec. For. 16(3), 241-252. https://doi.org/10.5424/srf/200716301013.

Calama, R., Mutke, S., Tomé, J., Gordo, J., Montero, G., and Tomé, M. (2011). Modelling spatial and temporal variability in a zero-inflated variable: the case of stone pine (Pinus pinea L.) cone production. Ecolog. Mod. 222(3), 606-618.

Calderón, A., Bustamante, J., Riu, N., and Pérez, S. (2008). Coniferous behavior under irrigation in Dique Yaucha, Mendoza, Argentina. J. Fac. Agric. Sci. UNCUYO 1, 67-72.

Castaño, J., Estirado, M., Abellanas, B., Butler, I., Cosano, I., Luengo, J., García, J., and Candela, J. (2004). Enhancement of Mediterranean forest resources. Grafting of stone pine (Pinus pinea L.). For. Rest. Man. No. 9, 248 pp.

Codesido, V., and Merlo, E. (2007). Inducción floral mediante aplicación de GA 4/7 y fertilización mineral en el huerto semillero de $P$. radiata de Sergude (Galicia). Inv. Agr.: Sist. Rec. For. 16(3), 262266.

Di Rienzo, J.A., Casanoves, F., Balzarini, M.G., Gonzalez, L., Tablada, M., and Robledo, C.W. (2013). InfoStat version 2014 (Córdoba, Argentina: Grupo InfoStat, FCA, Universidad Nacional de Córdoba), http://www.infostat.com.ar.

Ferrer, A., Herrero, G., Milián, C., and Aguirre, B. (2004). Carencias nutrimentales en coníferas cubanas. I. P. tropicalis. Forestal Baracoa 1, 23-28.

Kilci, M. (2013). Effects of nutrients on cone losses of stone pine $(P$. pinea L.) in Kozak Basin. In Mediterranean Stone Pine for Agroforestry, S. Mutke, M. Piqué, and R. Calama, eds. Options Méditerranéennes Série A, No. 105, 21-28.

Larcher, W. (2003). Physiological Plant Ecology: Ecophysiology and Stress Physiology of Functional Groups (Springer Science \& Business Media). https://doi.org/10.1007/978-3-662-05214-3.

Li, G., Wang, J., Oliet, J., and Jacobs, D. (2016). Combined pre-hardening and fall fertilization facilitates $\mathrm{N}$ storage and field performance of Pinus tabulaeformis seedlings. iForest, doi 10.3832/ifor1708-008.

Lodolini, E., Ali, S., Mutawea, M., Qutub, M., Arabasi, T., Pierini, F., and Neri, D. (2014). Complementary irrigation for sustainable production in olive groves in Palestine. Agric. Water Manag. 134, 104-109. https://doi.org/10.1016/j.agwat.2013.12.006.

Loewe, M.V., and Delard, R.C. (2012). A New Crop for Chile, Stone Pine (Pinus pinea L.) (Santiago, Chile: Forest Institute), 364 pp.

Loewe, V., Delard, C., and Venegas, A. (2012). Effect of fertilization on the production of female flowers in Stone pine (P. pinea). APA News (FAO) 41, 5-9. 
Loewe, M.V., and Delard, R.C. (2015). Informe gira técnica sobre pino pi-onero (P. pinea L.) a Turquía e Israel. Ciencia e Investig. For. 21(3), 53-92.

Loewe, V., Delard, C., Balzarini, M., Álvarez, A., and Navarro-Cerrillo, R. (2015). Impact of climate and management variables on stone pine (Pinus pinea L.) growing in Chile. Agric. For. Meteorol. 214/215, 106-116. https://doi.org/10.1016/j.agrformet.2015.08.248.

Loewe, V., Balzarini, M., Álvarez, A., Delard, C., and Navarro-Cerrillo, R. (2016). Fruit productivity of Stone pine (Pinus pinea L.) along a climatic gradient in Chile. Agric. For. Meteorol. 223, 1-14.

Malchi, T., and Shenker, M. (2011). Iron deficiency of $P$. pinea: evaluation of iron uptake mechanisms and comparison of genetic lines (Jerusalem, Israel), $42 \mathrm{pp}$.

Marschner, H. (2012). Marschner's Mineral Nutrition of Higher Plants, H. Marschner, ed. (Academic Press), Vol. 89, 651 pp.

McLain, R. (2008). Management guidelines for expanding Pinyon nut production in Colorado's Pinyon-Juniper woodlands (Institute for Culture and Ecology), 10 pp. http://www.ifcae.org/publications/ downloads/PJE_Mgmt_Guidelines_03-18-08.pdf (accessed Aug. 2011).

Mutke, S. (2005). Modelización de la arquitectura de copa y de la producción de pi-ón en plantaciones clonales de Pinus pinea L. Doctoral Thesis, Universidad Politécnica of Madrid, Madrid, Spain, 66 pp.

Mutke, S., Calama, R., González-Martínez, S., and Montero, G. (2012). Mediterranean Stone Pine: botany and horticulture. Hortic. Rev. 39, 53-201.

Oliveras, I., Martínez-Vilalta, J., Jimenez-Ortiz, T., Lledó, M.J., Escarré, A., and Piñol, J. (2003). Hydraulic properties of $P$. halepensis, $P$. pinea and Tetraclinis articulata in a dune ecosystem of Eastern Spain. Plant Ecol. 169, 131-141. https://doi.org/10.1023/A:1026223516580.

Omodei, B. (2014). Accuracy and uniformity of a gravity-feed method of irrigation. Irrig. Sci. 33(2), 121-130. https://doi.org/10.1007/ s00271-014-0452-2.

Pardos, M., Calama, R., Mayoral, C., Madrigal, G., and SánchezGonzález, M. (2015). Addressing post-transplant summer water stress in Pinus pinea and Quercus ilex seedlings. iForest 8, 348-358.

Pestaña, E.V. (2000). The stone pine, fruit tree. Proc. $1^{\text {st }}$ Symposium on Stone Pine, Valladolid, Spain, 2, 279-284.

Rapp, M., Leclerc, M., and Lossaint, P. (1979). The nitrogen economy in a Pinus pinea L. stand. For. Ecol. Manag. 2(3), 221-231. https:// doi.org/10.1016/0378-1127(79)90048-3.

Ravazi, S., Azizi, P., Rashidi, R., and Keivan, F. (2006). The effect of NPK fertilizers on hand planting Pinus pinea in coastal areas of Caspian Sea. Iranian J. Nat. Res. 59(2), 377-389.

Rottoli, M., and Castiglioni, E. (2011). Plant offerings from Romans cremations in northern Italy: a review. Veget. Hist. Archaeobot. 20, 495-506. https://doi.org/10.1007/s00334-011-0293-3.

Ruano, J.R. (2008). Viveros Forestales, 2 ${ }^{\text {nd }}$ ed. (Madrid, Spain), 285 pp.

Sansavini, S., and Ranalli, P. (2012). Manuale di Ortofrutticoltura (Italy: Ed. Edagricole), 667 pp.

Schlatter, J.E., and Gerding, V. (1984a). Deficiencia de Boro en Plantaciones de Pinus radiata D. Don en Chile I. Distribución y origen. Bosque 6(1), 24-31. https://doi.org/10.4206/bosque.1985. v6n1-03.
Schlatter, J.E., and Gerding, V. (1984b). Deficiencia de Boro en Plantaciones de Pinus radiata en Chile II. Principales causas y corrección. Bosque 6(1), 32-43. https://doi.org/10.4206/ bosque.1985.v6n1-04

Segura, R., and Lizarraga, E.R. (2006). Other relevant components of nuts, phytosterols, folate and minerals. Br. J. Nutr. 96, S36-S44. https://doi.org/10.1017/BJN20061862.

Tagliavini, M. (2014). La fertilizzazione nell'arboreto. In Arboricoltura Generale, S. Sansavini, G. Costa, R. Gucci, P. Inglese, A. Ramina, and C. Xiloyannis, eds. (Bologna, Italy: Ed. Patron), p. 425-443.

Villar-Salvador, P., Puértolas, J., Peñuelas, J.L., and Planelles, R. (2005). Effect of nitrogen fertilization in the nursery on the drought and frost resistance of Mediterranean forest species. Inv. Agr: Sist. Rec. For. 14(3), 408-418. https://doi.org/10.5424/srf/2005143-00935.

Xyloyannis, C. (2014). L'acqua e gli apporti irrigui. In Arboricoltura Generale, S. Sansavini, G. Costa, R. Gucci, P. Inglese, A. Ramina, and C. Xiloyannis, eds. (Bologna, Italy: Ed. Patron), p. 399-424.

Zas, R., and Fernández-López, J. (2005). Juvenile genetic parameters and genotypic stability of Pinus pinaster. Open-pollinated families under different water and nutrient regimes. For. Sci. 51(2), 165-174.

Received: Apr. 5, 2017

Accepted: Jul. 25, 2017 